\title{
EVALUATING THE PERFORMANCE OF INDIAN BANKING SECTOR USING DEA DURING POST-REFORM AND GLOBAL FINANCIAL CRISIS
}

\author{
Mukesh KUMAR ${ }^{1}$, Vincent CHARLES ${ }^{2}$, Chandra SEKHAR MISHRA ${ }^{3}$ \\ 1,2 CENTRUM Católica Graduate Business School, \\ Pontificia Universidad Católica del Perú, Lima, Peru \\ ${ }^{3}$ Vinod Gupta School of Management, Indian Institute of Technology, Kharagpur, India \\ E-mails: ${ }^{1}$ mkumar@pucp.pe (corresponding author); ${ }^{2}$ vcharles@pucp.pe; \\ ${ }^{3}$ csmishra@vgsom.iitkgp.ernet.in
}

Received 13 November 2012; accepted 27 May 2013

\begin{abstract}
The purpose of the study is to examine the performance of Indian banking sector in terms of efficiency, returns to scale, and total factor productivity change. The technique of data envelopment analysis is applied due to its flexibility to incorporate multiple inputs and multiple outputs without any underlying assumption on the functional form. There is growing tendency of public sector banks operating under increasing returns to scale, implying that substantial gains could be obtained from altering scale via either internal growth or consolidation in the sector. In terms of productivity, the results show a positive change in both the sectors due to technological change, possibly as a result of adoption of latest technology and new business practices in post reform period. However, there is an evidence of shrink in the market and negative growth in productivity in both the sectors during the period of global financial crisis. The main contribution of the paper is to empirically provide the evidences to resolve the debate if the global financial crisis had any impact on the performance of banking sector in India.
\end{abstract}

Keywords: data envelopment analysis, Indian banking sector, global financial crisis, efficiency, returns to scale, total factor productivity change.

JEL Classification: C44, D22, D24, G21.

\section{Introduction}

A sound financial system is crucial for an indispensable and vibrant economy. Thus, the performance of any economy to a large extent is dependent on the performance of the banking sector as it being the predominant component of the financial service industry. The Indian banking sector went through structural changes since its independence keeping in view its financial linkages with the rest of the economy and to meet the social and economic objectives of development (Kumbhakar, Sarkar 2005). Consequently, the sector was initially following strict controls on interest rates, as well as stringent regulations relating to branch licensing, directed credit programs, and mergers. However, the 
closed and strict regulated environment started showing adverse affect on the sector, resulting in under-performance of the banks over the years. As a result, Indian banking sector underwent a sea of changes through its liberalization policy in early 1990s with implementation of a series of reforms (see Bhide et al. 2001; Reddy 2006; Prasad, Ghosh 2007; Kumar, Charles 2011 for extensive review of the recent banking sector reform) with an objective to make the banking sector more productive and efficient by limiting the state intervention and enhancing the role of market forces.

However, the turmoil in the international financial markets of advanced economies that started around mid-2007 has exacerbated substantially since August 2008. The first hint of the trouble came from the collapse of two Bear Stearns hedge funds in early 2007 (Prasad, Reddy 2009). Subsequently a number of other banks and financial institutions also began to show signs of distress. Matters really came to the force with the bankruptcy of Lehman Brothers, a big investment bank, in September 2008. In spite of the fact that Indian banking system is not directly exposed to the sub-prime mortgage assets, the shock has been felt in Indian financial market as well, since India is far more exposed to international markets after macro-economic reforms of 1991. The financial sector, especially banks, is subject to prudential regulations, both in regard to capital and liquidity. As the current global financial crisis has shown, liquidity risks can increase manifold during a crisis and can pose serious downside risks to macroeconomic and financial stability (Mohan 2008). The RBI's policy response aimed at containing the contagion from the outside in order to keep the domestic money and credit markets functioning normally and see that the liquidity stress does not trigger solvency cascades (Subbarao 2009). In particular, three objectives were targeted: first, to maintain a comfortable rupee liquidity position; second, to augment foreign exchange liquidity; and third, to maintain a policy framework that would keep credit delivery on track so as to arrest the moderation in growth.

The literature on performance of Indian banking sector reveals mixed experiences of liberalization policies. Das (1997) in his study for the period 1990-1996 observed decline in technical efficiency (TE) with slight improvement in allocative efficiency of public sector banks (PSBs). On the other hand, Saha and Ravisankar (2000) observed that barring few exceptions, the PSBs in general have improved their efficiency during the period, 1992-1995. In a comparative study based on ownership, Bhattacharya et al. (1997) found that the PSBs were the best performing banks, while the new private sector banks were yet to emerge fully in the Indian banking scenario. Sathye (2003) found that the PSBs were on average more efficient than foreign banks, which in turn were more efficient than private banks. However, Sahoo et al. (2007) who examined the efficiency trends of the Indian commercial banks during the period 1998 to 2005 observed the contrary results; foreign banks are seen outperforming over both the nationalized banks and private banks, and private and foreign banks as a group outperforming over the nationalized banks.

However, one of the major limitations of all the above studies is that they focused on only one aspect of performance measurement, i.e., efficiency. Controversy is not only concerned with whether deregulation stimulates efficiency but also on different sources 
of productivity growth. While some studies attribute productivity growth to technological progress (Avkiran 2000; Alam 2001; Canhoto, Dermine 2003; Kumbhakar et al. 2001; Sturm, Williams 2004) others are in favour of efficiency improvement (Berg et al. 1992; Gilbert, Wilson 1998; Isik, Hassan 2003). In the Indian context, Galagedera and Edirisuriya (2005) observed PSBs with a modest growth in TFP due to technological progress and no indication of any growth in private sector banks for the period 19952002. Zhao et al. (2008) in their study for the period 1992-2004 observed that after an initial adjustment phase of deregulation period, the Indian banking sector experienced sustained productivity growth, driven mainly by technological progress. Bank's ownership structure seems to have an impact on bank efficiency but doesn't appear to have an influence on total factor productivity (TFP) change. Similarly, Kumar et al. (2010) observed that TFP change for Indian banking sector for the period of 1995-2006 was driven mainly by technological change (TC) as compared to efficiency change.

There has been debate among the policy makers, bankers and researchers since the mid of 2007 whether the global financial crisis had any impact on the performance of India banking sector. It is believed that Indian banking sector is unlikely to get affected with global financial crisis as (i) the banking system in India has had no direct exposure to the sub-prime mortgage assets or to the failed institutions. (ii) India's recent growth has been driven predominantly by domestic consumption and domestic investment with very limited reliance of external demand. Other contrary view is that with the increasing integration of the Indian economy and its financial markets with rest of the world, there is possibility that the country does face some downside risks from these international developments. However, no attempt has been made till date to empirically resolve this debate.

The current study uses data envelopment analysis (DEA) to examine the performance of Indian banking sector and two major ownership structures within it in terms of efficiency, returns to scale and TFP change for 15 years of post-liberalization period as well as two sub-periods: (i) pre global financial crisis period and (ii) global financial crisis period. The rest of the paper proceeds as follows. The next section briefly presents the DEA models for measuring efficiency, returns to scale and TFP change. Next, the paper provides the detailed description of data, followed by results of the empirical analysis. Finally, the paper concludes with some implications.

\section{Methodology}

\subsection{The reference technology}

Let us consider a sample of $J$ decision making units (DMUs) from an industry producing a vector of $M$ outputs $(y)$ from a vector of $N$ inputs $(x)$. Let $B$ denotes $J \times M$ matrix of observed outputs and $A$ denotes the $J \times N$ matrix of observed inputs. Individual elements of $B$, denoted by $y_{m}^{j}$ measure the quantity of $m^{\text {th }}$ output produced by the $j^{\text {th }}$ DMU, while the individual elements of $A$, denoted by $x_{n}^{j}$, measure the employment level of $n^{\text {th }}$ input by the $j^{\text {th }}$ DMU. A production technology at time $t$ transforming input vector $x^{t}$ to output vector $y^{t}$ can be represented by the graph of technology GRt: 


$$
G R^{t}\left(x^{t}, y^{t}\right)=\left\{\left(x^{t}, y^{t}\right): x^{t} \geq \sum_{j=1}^{J} \lambda_{j} x^{j, t} ; y^{t} \leq \sum_{j=1}^{J} \lambda_{j} y^{j, t} ; \lambda_{j} \geq 0\right\},
$$

which exhibits constant returns to scale (CRS) and strong disposability of inputs and outputs (Färe et al. 1994). Following Afrait (1972), the assumption of CRS can be relaxed to allow for variable returns to scale (VRS) by putting the restriction in (1): $\sum_{j=1}^{J} \lambda_{j}=1$ (Banker et al. 1984), where $\lambda_{j}$ is an intensity variable indicating the level of intensity at which a particular activity (DMU) may be employed in production.

\subsection{The distance function}

Following Shephard (1970) and Färe (1988), the output distance function in time period $t$ is defined as:

$$
D^{t}\left(x^{t}, y^{t}\right)=\inf \left\{\theta:\left(x^{t}, y^{t} / \theta\right) \in G R^{t}\right\}=\left[\sup \left\{\theta:\left(x^{t}, \theta y^{t}\right) \in G R^{t}\right\}\right]^{-1} .
$$

It is to be noted that $D^{t}\left(x^{t}, y^{t}\right) \leq 1$ if and only if $\left(x^{t}, y^{t}\right) \in G R^{t}$. In addition, $D^{t}=1$, if and only if $\left(x^{t}, y^{t}\right)$ is on the boundary or frontier of the technology. This function is reciprocal to Farrell's (1957) output oriented measures of technical efficiency (TE), i.e., the reciprocal of the maximum proportional expansion of the output vector, $y^{t}$ given the input vector $x^{t}$.

\subsection{Measurement of output technical efficiency}

The output-oriented distance function under CRS technology can be obtained by using the following the CCR Model (Charnes et al. 1978).

Model I: Output-oriented single-period distance function under CRS (CCR Model):

$$
\begin{aligned}
& {\left[D_{c}^{t}\left(x^{j^{\prime}, t}, y^{j^{\prime}, t}\right)\right]^{-1}=\operatorname{Max} \theta_{c}^{j^{\prime}, t},} \\
& \text { s.t. } \sum_{j=1}^{J} \lambda_{j} x_{n}^{j, t} \leq x_{n}^{j^{\prime}, t} ; \sum_{j=1}^{J} \lambda_{j} y_{m}^{j, t} \geq \theta_{c}^{j^{\prime}, t} y_{m}^{j^{\prime}, t} ; \lambda_{j} \geq 0, \forall j .
\end{aligned}
$$

The output-oriented single period distance function measures the maximum proportional change in outputs required to make $\left(x^{t}, y^{t}\right)$ feasible in relation to the technology at time period $t$. In other words, the efficiency of DMU in time period $t$ is evaluated with reference to the technology in the same time period $t$. The output distance function under VRS technology can be obtained by adding additional convexity constraint $\sum_{j=1}^{J} \lambda_{j}=1$ in CCR model, popularly known as BCC model (Banker et al. 1984).

Model II: Output-oriented single period distance function under VRS (BCC Model):

$$
\begin{aligned}
& {\left[D_{v}^{t}\left(x^{j^{\prime}, t}, y^{j^{\prime}, t}\right)\right]^{-1}=\operatorname{Max} \theta_{v}^{j^{\prime}, t},} \\
& \text { s.t. } \sum_{j=1}^{J} \lambda_{j} x_{n}^{j, t} \leq x_{n}^{j^{\prime}, t} ; \sum_{j=1}^{J} \lambda_{j} y_{m}^{j, t} \geq \theta_{v}^{j^{\prime}, t} y_{m}^{j^{\prime}, t} ; \sum_{j=1}^{J} \lambda_{j}=1 ; \lambda_{j} \geq 0, \forall j .
\end{aligned}
$$




\subsection{Measurement of returns to scale}

Decomposing TE into pure efficiency (PE) and scale efficiency (SE) allows an insight into the sources of inefficiencies. It also helps to determine whether banks operate under optimal or non-optimal returns to scale. The CRS efficiency score obtained from the model I represents TE, which measures inefficiencies due to the input/output configuration and as well as the size of operations. On the other hand, the VRS efficiency score obtained from the model II represents PE, that is, a measure of efficiency without SE. The SE can be obtained as the ratio of TE to PE.

Once the SE scores are computed, the analysis can be taken a step further. This involves determining whether a particular DMU is experiencing the optimal scale, operating under CRS or non-optimal returns to scale, either operating under IRS or DRS. To make this assessment, DEA is repeated with non-IRS (NIRS) by incorporating the restriction $\sum_{j=1}^{J} \lambda_{j} \leq 1$ in the model I. If the score for a DMU under VRS equals the NIRS score, it implies that DMU operates under DRS. If not; it implies that DMU operates under IRS (Coelli et al. 1998). If the VRS score equals the CRS score, then the DMU is said to be operating at the optimal scale or the most productive scale size.

\subsection{Measurement of Malmquist productivity index}

To define a Malmquist productivity index, let us define the output-oriented distance functions with respect to two different time periods as follows:

and

$$
D^{t}\left(x^{t+1}, y^{t+1}\right)=\inf \left\{\theta:\left(x^{t+1}, y^{t+1} / \theta\right) \in G R^{t}\right\}
$$

$$
D^{t+1}\left(x^{t}, y^{t}\right)=\inf \left\{\theta:\left(x^{t}, y^{t} / \theta\right) \in G R^{t+1}\right\} .
$$

The first mixed-period distance function in (5) measures the maximum proportional change in outputs required to make $\left(x^{t+1}, y^{t+1}\right)$ feasible in relation to the technology at time period $t$. Similarly, the second mixed-period distance function in (5) measures the maximum proportional change in outputs required to make $\left(x^{t}, y^{t}\right)$ feasible in relation to the technology at time period $t+1$. In both these mixed-period cases, the value of the distance function may exceed unity if the observation being evaluated is not feasible in the other period.

Following Ray and Desli (1997), the Malmquist productivity index with respect to time period $t$ and $t+1$ can be defined respectively as:

$$
\begin{aligned}
& M^{t}=\frac{D_{c}^{t}\left(x^{t+1}, y^{t+1}\right)}{D_{c}^{t}\left(x^{t}, y^{t}\right)}=\frac{D_{v}^{t}\left(x^{t+1}, y^{t+1}\right)}{D_{v}^{t}\left(x^{t}, y^{t}\right)} \times \frac{D_{c}^{t}\left(x^{t+1}, y^{t+1}\right) / D_{v}^{t}\left(x^{t+1}, y^{t+1}\right)}{D_{c}^{t}\left(x^{t}, y^{t}\right) / D_{v}^{t}\left(x^{t}, y^{t}\right)}= \\
& \frac{D_{v}^{t}\left(x^{t+1}, y^{t+1}\right)}{D_{v}^{t}\left(x^{t}, y^{t}\right)} \times \frac{S E^{t}\left(x^{t+1}, y^{t+1}\right)}{S E^{t}\left(x^{t}, y^{t}\right)}, \\
& M^{t+1}=\frac{D_{v}^{t+1}\left(x^{t+1}, y^{t+1}\right)}{D_{v}^{t+1}\left(x^{t}, y^{t}\right)} \times \frac{S E^{t+1}\left(x^{t+1}, y^{t+1}\right)}{S E^{t+1}\left(x^{t}, y^{t}\right)} .
\end{aligned}
$$


By taking the geometric mean of (6) and (7), we get:

$$
M=\left[\frac{D_{v}^{t}\left(x^{t+1}, y^{t+1}\right)}{D_{v}^{t}\left(x^{t}, y^{t}\right)} \times \frac{D_{v}^{t+1}\left(x^{t+1}, y^{t+1}\right)}{D_{v}^{t+1}\left(x^{t}, y^{t}\right)}\right]^{\frac{1}{2}} \times\left[\frac{S E^{t}\left(x^{t+1}, y^{t+1}\right)}{S E^{t}\left(x^{t}, y^{t}\right)} \times \frac{S E^{t+1}\left(x^{t+1}, y^{t+1}\right)}{S E^{t+1}\left(x^{t}, y^{t}\right)}\right]^{\frac{1}{2}} .
$$

The first component of (8) can be further decomposed as:

$$
\left[\frac{D_{v}^{t}\left(x^{t}, y^{t}\right)}{D_{v}^{t+1}\left(x^{t}, y^{t}\right)} \frac{D_{v}^{t}\left(x^{t+1}, y^{t+1}\right)}{D_{v}^{t+1}\left(x^{t+1}, y^{t+1}\right)}\right]^{\frac{1}{2}} \times\left[\frac{D_{v}^{t+1}\left(x^{t+1}, y^{t+1}\right)}{D_{v}^{t}\left(x^{t}, y^{t}\right)}\right],
$$

where the first component of (9) is the geometric mean of two ratios, which measures the shift in the technology calculated at $x^{t}$ and $x^{t+1}$. The second component measures the change in relative efficiency between the years $t$ and $t+1$. The second component of (8) which involves both CRS and VRS distance functions at both the time periods, measures the change in SE. Thus, Malmquist productivity index is the product of TC, $\mathrm{PE}$ change and SE change.

The single-period distance functions under the CRS and VRS are solved using models I and II respectively; whereas the mixed-period distance functions under CRS are solved using models III and IV as follows:

Model III: Output-oriented mixed period distance function with respect to technology at time period $t$ :

$$
\begin{aligned}
& {\left[D_{c}^{t}\left(x^{j^{\prime}, t+1}, y^{j^{\prime}, t+1}\right)\right]^{-1}=\operatorname{Max} \theta_{c}^{j^{\prime}, t},} \\
& \text { s.t. } \sum_{j=1}^{J} \lambda_{j} x_{n}^{j, t} \leq x_{n}^{j^{\prime}, t+1} ; \sum_{j=1}^{J} \lambda_{j} y_{m}^{j, t} \geq \theta_{c}^{j^{\prime}, t} y_{m}^{j^{\prime}, t+1} ; \lambda_{j} \geq 0, \forall j .
\end{aligned}
$$

Model IV: Output-oriented mixed period distance function with respect to technology at time period $t+1$ :

$$
\begin{aligned}
& {\left[D_{c}^{t+1}\left(x^{j^{\prime}, t}, y^{j^{\prime}, t}\right)\right]^{-1}=\operatorname{Max} \theta_{c}^{j^{\prime}, t+1},} \\
& \text { s.t. } \sum_{j=1}^{J} \lambda_{j} x_{n}^{j, t+1} \leq x_{n}^{j^{\prime}, t} ; \sum_{j=1}^{J} \lambda_{j} y_{m}^{j, t+1} \geq \theta_{c}^{j^{\prime}, t+1} y_{m}^{j^{\prime}, t} ; \lambda_{j} \geq 0, \forall j .
\end{aligned}
$$

In models I and II, $\left(x^{j^{\prime}, t}, y^{j^{\prime}, t}\right) \in G R^{t}$ and therefore, $D_{c}^{t}\left(x^{j^{\prime}, t}, y^{j^{\prime}, t}\right) \leq 1$. However, in models III and IV, $\left(x^{j^{\prime}, t+1}, y^{j^{\prime}, t+1}\right)$ need not to belong to $G R^{t}$ and so it may take value greater than 1. The mixed-period distance functions under the VRS are solved using models III and IV with the restriction on sum of intensity variables, i.e., $\sum_{j=1}^{J} \lambda_{j}=1$. 


\section{The data}

Following Berger and Humphrey (1997), we have used intermediation approach ${ }^{1}$ with restricted choice of variables ${ }^{2}$. The choice of the inputs and outputs are guided by the choices made in previous studies and also on the data availability. In the current study, we have used two inputs - total cost and total deposits. The input total cost is measured as the sum of total interest expenses and non-interest expenses including personal expenses. Non-interest expenses include service charges and commissions, expenses of general management affairs, salaries, and other expenses (including health insurance and securities portfolios). Some researchers (Yeh 1996; Sathye 2003; Ram Mohan, Ray 2004; Kao, Liu 2004) have treated interest expenses and non-interest expenses as two different inputs along with other inputs. However, following Charles and Kumar (2012) and Kumar and Charles (2011), we have treated both together as a single input as total cost. This kind of treatment is mainly due to the well known dimensionality problem associated with DEA particularly with limited sample size: a high number of variables relative to the number of observations cause more units to be wrongly identified as efficient (Zhao et al. 2008). The input, total deposit is taken as the sum of demand and savings deposits held by bank and non-bank depositors. The above two inputs are used to produce two outputs namely, total loans and other earning assets. The output, total loan is measured as the sum of all loan accounts intermediated by banks and the output, other earning assets is measured as the sum of total securities (treasury bills, government bonds and other securities), deposits with banks and equity investments. To ensure the validity of the DEA model specification, an isotonicity test (Avkiran 1999) was conducted, which involves the calculation of all inter-correlations between inputs and outputs for identifying whether increasing amounts of inputs lead to greater outputs. The inter-correlation between inputs and outputs were observed positive (Pearson correlations $>0.80 ; \alpha=0.01$ ), the isotonicity test was passed and the inclusion of inputs/ outputs was justified.

The basic data on inputs and outputs has been taken from PROWESS electronic database, provided by Centre for Monitoring Indian Economy (CMIE), Pvt. Ltd. Mumbai for the period spanning 1995-1996 to 2009-2010. The sample consists of commercial banks including both public and private banks for which the data were available for the entire period. There were 35 commercial banks in total for which the data were available during the study period. However, one of the private banks, Kotak Mahindra Bank Ltd. was dropped from the sample because of excessive missing data. Another private bank, i.e., ICICI Bank Ltd. was dropped from the sample as it did not fit into any of the broad cluster during the screening of the data. Nunamaker (1985) and Raab and Lichty (2002) suggested a rule of thumb on deciding the minimum size of the sample in any DEA study. The sample size should be at least three times larger than the sum of the

\footnotetext{
${ }^{1}$ The justification on choice of intermediary approach in the present case can be viewed in Kumar and Charles (2011).

${ }^{2}$ An increase in the number of outputs or inputs leads to an increase in efficiency scores. In small samples with many variables almost all units may be on the frontier.
} 
number of inputs and outputs. In our study, with a total of two inputs and two outputs, we ended up with a reasonably good sample size of 33 banks (see Table 1) consisting of 19 public banks and 14 private banks. However the sample for the period 2008-2010 is confined to 32 banks due to the merger of CBPL with HDFCBL in the year 2008.

Table 1. List of banks

\begin{tabular}{|c|c|c|c|c|c|}
\hline $\mathrm{SN}$ & $\begin{array}{l}\text { Abbrevia- } \\
\text { tion }\end{array}$ & Name of the bank & $\mathrm{SN}$ & $\begin{array}{l}\text { Abbrevia- } \\
\text { tion }\end{array}$ & Name of the bank \\
\hline 1 & $\mathrm{AB}$ & Allahabad Bank ${ }^{1}$ & 18 & IOB & Indian Overseas Bank $^{1}$ \\
\hline 2 & AnB & Andhra Bank ${ }^{1}$ & 19 & IBL & Indusind Bank Ltd. $^{2}$ \\
\hline 3 & BOB & Bank of Baroda $^{1}$ & 20 & JKBL & Jammu $\&$ Kashmir Bank Ltd. $^{2}$ \\
\hline 4 & BOI & Bank of India ${ }^{1}$ & 21 & KBL & Karnataka Bank Ltd. $^{2}$ \\
\hline 5 & $\mathrm{BOM}$ & Bank of Maharashtra $^{1}$ & 22 & KVBL & Karur Vysya Bank Ltd. ${ }^{2}$ \\
\hline 6 & BORL & Bank of Rajasthan Ltd. ${ }^{2}$ & 23 & LVBL & Lakshmi Vilas Bank Ltd. $^{2}$ \\
\hline 7 & $\mathrm{CB}$ & Canara Bank ${ }^{1}$ & 24 & OBOC & Oriental Bank of Commerce $^{1}$ \\
\hline 8 & CBOPL & $\begin{array}{l}\text { Centurion Bank of Punjab } \\
\text { Ltd. }^{2}\end{array}$ & 25 & PNB & Punjab National Bank ${ }^{1}$ \\
\hline 9 & CUBL & City Union Bank Ltd. ${ }^{2}$ & 26 & SIBL & South Indian Bank Ltd. ${ }^{2}$ \\
\hline 10 & $\mathrm{CoB}$ & Corporation Bank ${ }^{1}$ & 27 & SBBJ & $\begin{array}{l}\text { State Bank of Bikaner \& } \\
\text { Jaipur }^{1}\end{array}$ \\
\hline 11 & DB & Dena Bank ${ }^{1}$ & 28 & SBI & State Bank of India ${ }^{1}$ \\
\hline 12 & DCBL & $\begin{array}{l}\text { Development Credit Bank } \\
\text { Ltd. }^{2}\end{array}$ & 29 & SBM & State Bank of Mysore ${ }^{1}$ \\
\hline 13 & DBL & Dhanalakshmi Bank Ltd. ${ }^{2}$ & 30 & SB & Syndicate Bank ${ }^{1}$ \\
\hline 14 & FBL & Federal Bank Ltd. $^{2}$ & 31 & UB & Uco Bank $^{1}$ \\
\hline 15 & HDFCBL & H D F C Bank Ltd. ${ }^{2}$ & 32 & UBI & Union Bank of India ${ }^{1}$ \\
\hline 16 & INGVBL & I N G Vysya Bank Ltd. $^{2}$ & 33 & VB & Vijaya Bank $^{1}$ \\
\hline 17 & IB & Indian Bank ${ }^{1}$ & & & \\
\hline
\end{tabular}

Note: superscript 1 and 2 respectively indicate that the corresponding bank is public and private bank.

\section{Empirical findings}

Though, the commercial banks are homogeneous with respect to their organizational structure, goals and objectives, they differ significantly in size and production level. So, scale of banks plays a vital role in their relative efficiency. The CCR measures of TE captures not only the productive inefficiency of a bank at its actual scale size, but also some inefficiency resulting from its actual scale size being different from the most productive scale size (Banker et al. 1984). If a DMU is scale efficient, it implies that it operates under the most productive scale size and thus, maximizes its average productivity. As the productivity growth could be achievable solely through reduction 
in wastefulness or through the change in scale of operation, without resort to new technology, we begin our discussion with the issue of efficiency and scale of production in Indian banking sector.

\subsection{Productive efficiency}

Table 2 provides the summary statistics of TE and its components in Indian banking sector during the period 1996 to 2010 along with their average trends shown in Figure 1(a) to 1(c), respectively. Out of total 33 banks in the sample the number of efficient banks varies from 3 to 8 with average TE score varying from 0.859 to 0.946 during the period of study. The percentage of banks found to be technically efficient in the private sector is more than that in public sector throughout the period, except during the year 2008. The average TE of PSBs varies from 0.828 to 0.955 and that of private sector banks varies from 0.877 to 0.940 . However, the difference in the average TE scores between the above two types of banks is found to be insignificant except during the year 1999. As it can be observed from Figure 1(a), the private sector banks are performing faintly better than the PSBs during 1996 to 2004 except in the years1998 and 2003. However, the PSBs are continuously performing better than private sector banks since 2005 onwards.

The nature of technical inefficiency may be due to ineffective implementation of the production plan of the banks in converting inputs to outputs and due to the divergence of the bank from the most productive scale size. Thus, decomposition of TE into PE and SE allows an insight into the sources of inefficiency. Larger the difference between PE and TE, more scale inefficient a bank is, which in turn, indicates the larger deviation of the bank from the most productive scale size.

The average PE score of public varies from 0.905 to 0.970 and that of private sector banks varies from 0.920 to 0.976 . The PSBs has surpassed the private sector banks in terms of PE till 1999 and the reverse is true since 2001 onwards except for the years 2003 and 2006. However, the average PE score does not differ significantly between two types of banks except for the year 1998. The average SE score of PSBs varies from 0.914 to 0.994 and that of private sector banks varies from 0.942 to 0.988 . The difference in the average SE is found to be statistically significant between public and private sector banks during 1999, 2000, 2005 and 2007. On an average, the private sector banks are performing better than the PSBs in terms of SE till 2001. However, the scenario is just the reverse since 2002 onwards.

One can observe from Table 3 that in spite of global financial crisis, both public as well as private sector banks are performing better in terms of TE in sub-period II and it continues to show increasing trends. However, it will be misleading to conclude at this stage that Indian banking sector has been operating completely under the clear sky during the global financial crisis period. It could be vital to address the issue through other performance measures such as returns to scale and mixed period Malmquist productivity index before we arrive at any definite conclusion. 


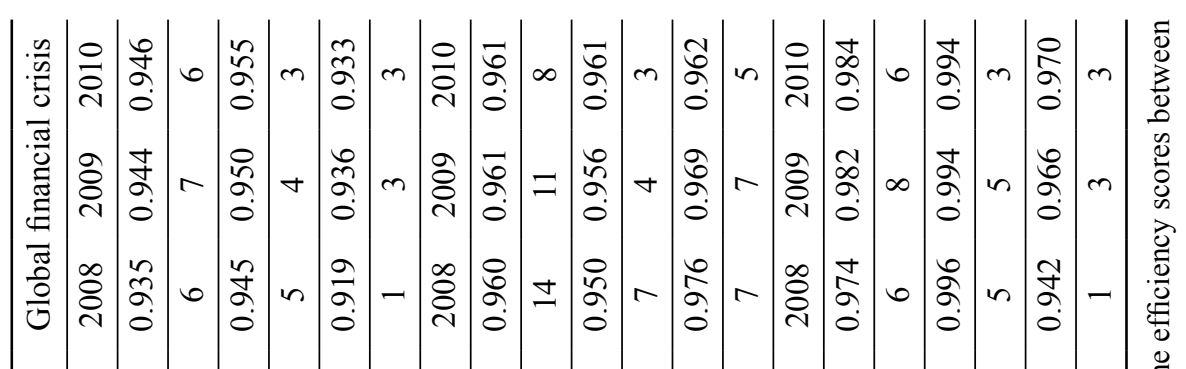

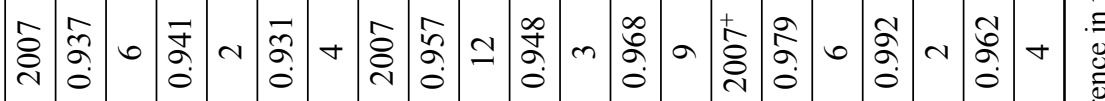

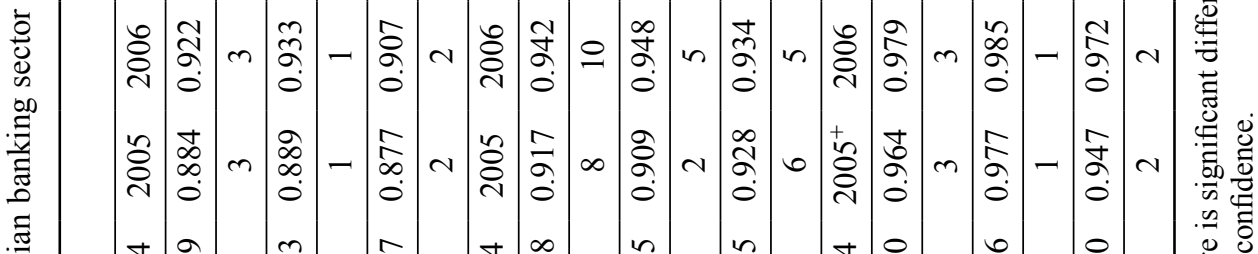

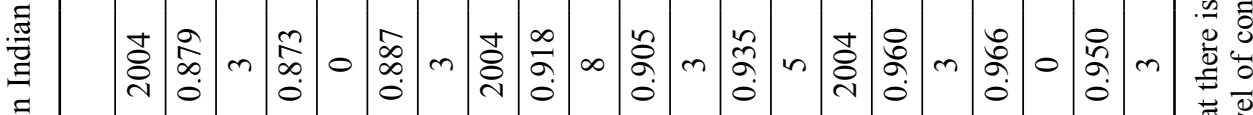

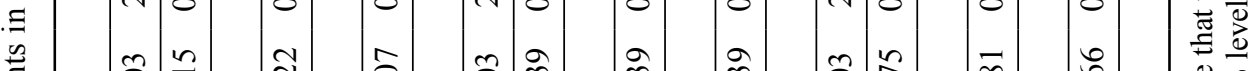

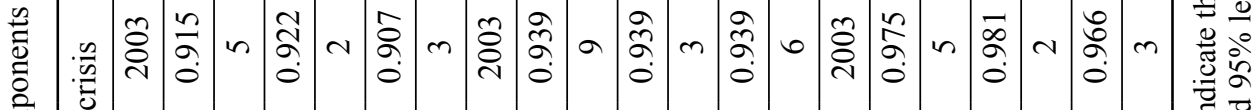

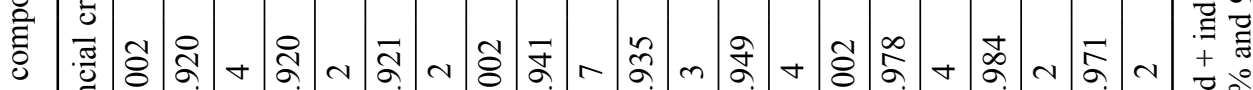

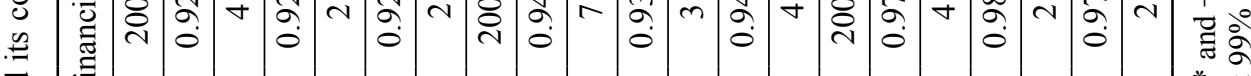

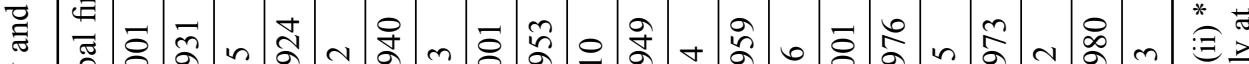

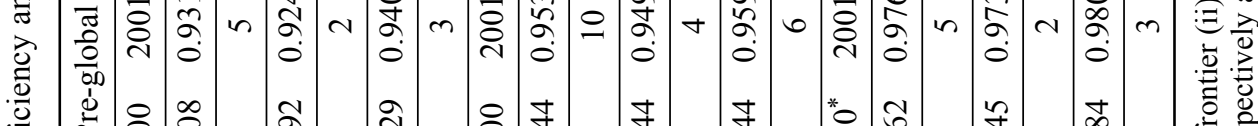

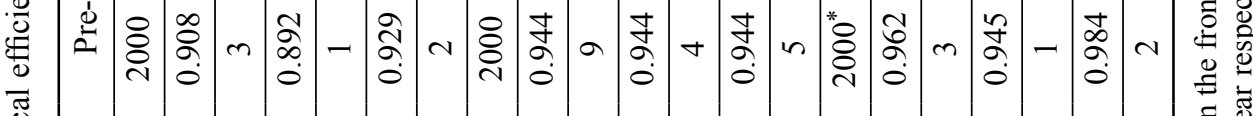

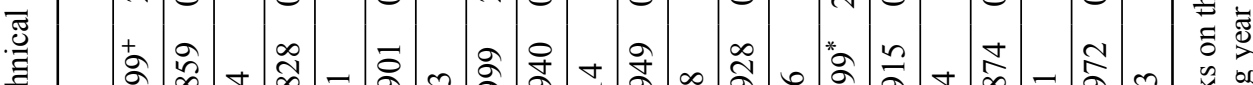

i

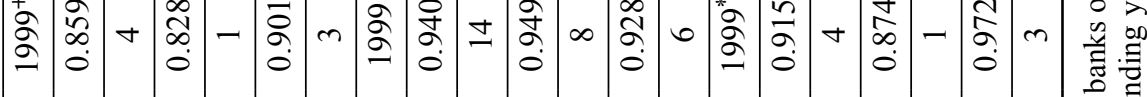

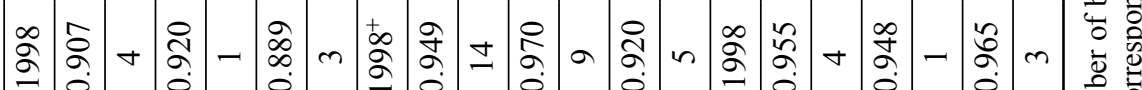

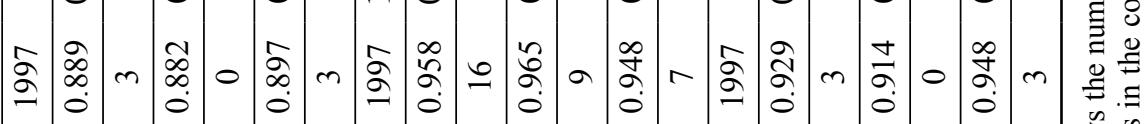

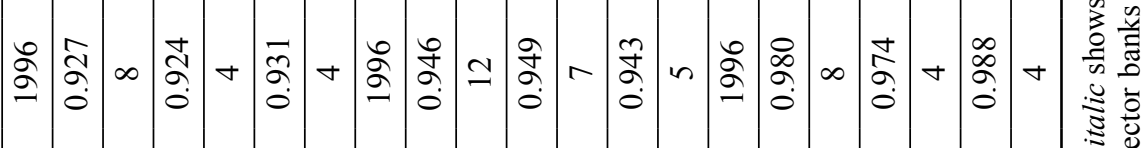

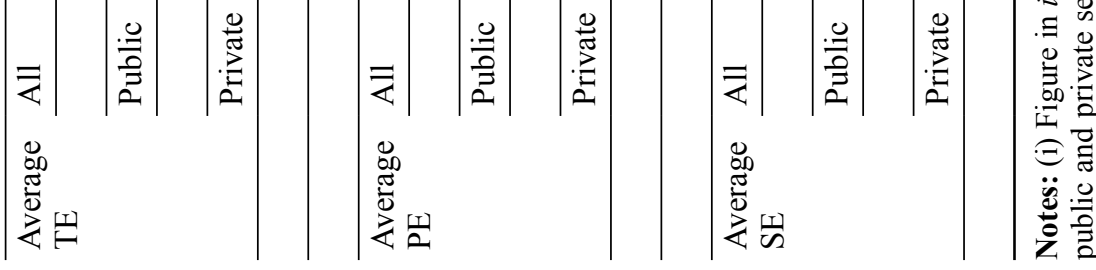


Table 3. Summary statistics of technical efficiency and its components in different time periods

\begin{tabular}{lccccccccc}
\hline & \multicolumn{2}{c}{$\begin{array}{c}\text { Pre-global financial crisis } \\
\text { (1996 to 2007) }\end{array}$} & \multicolumn{2}{c}{$\begin{array}{c}\text { Global financial crisis } \\
(2008 \text { to 2010) }\end{array}$} & \multicolumn{3}{c}{$\begin{array}{c}\text { Post-liberalization } \\
\text { (1996 to 2010) }\end{array}$} \\
\cline { 2 - 10 } & TE & PE & SE & TE & PE & SE & TE & PE & SE \\
\hline All banks & 0.906 & 0.942 & 0.963 & 0.942 & 0.961 & 0.980 & 0.913 & 0.946 & 0.966 \\
\hline $\begin{array}{l}\text { Public } \\
\text { banks }\end{array}$ & 0.904 & 0.943 & 0.960 & 0.950 & 0.956 & 0.994 & 0.913 & 0.945 & 0.967 \\
\hline $\begin{array}{l}\text { Private } \\
\text { banks }\end{array}$ & 0.910 & 0.941 & 0.967 & 0.929 & 0.969 & 0.960 & 0.913 & 0.946 & 0.965 \\
\hline
\end{tabular}

Note: TE, PE and SE respectively indicate technical efficiency, pure efficiency and scale efficiency.

\subsection{Returns to scale}

The presence of scale inefficiency in a bank indicates that it does not operate under the optimal scale and thus, efficiency gains could be achieved by either expanding the production level for a bank operating under IRS or contracting the production level for a bank operating under DRS. Table 4 reports the summary statistics of returns to scale in Indian banking sector during the period of study. As it appears from Table 4, most of the banks operate at non-optimal scale (IRS or DRS). Only $9 \%$ to $33 \%$ of banks in the sample operate under optimal scale. It is worth noting that the number of banks that operate under DRS declines over a period of time and banks that operate under IRS increases over a period of time.

The percentage of banks that operate at optimal scale is higher in the private sector than its counterpart throughout except during the years 2006, 2008 and 2009. Most of the banks in the public sector operate at DRS. On the other hand, majority of the banks in the private sector operate at IRS. The finding is well supported with the study of Zhao et al. (2008) who found that a substantial proportion of PSBs remain characterized by DRS, whereas, two-third of foreign and private banks operate under IRS and optimal returns to scale during the period 1992-2004. Figure 1(d) to 1(f) shows the percentage of banks operating under optimal, decreasing and increasing returns to scale respectively during the period 1996 to 2010. One can observe from Figure 1(e) that (i) the percentage of PSBs operating under DRS is substantially higher than that of private sector banks at any point of time (ii) on an average, percentage of banks operating under DRS declines over a period of time for both the sectors. Similarly, it can be observed from Figure 1(f) that (i) the percentage of PSBs operating under IRS is substantially higher than that of private sector banks and (ii) on an average, percentage of banks operating under IRS increases over a period of time for both the sectors. There is sharp decline (increase) in number of banks operating under DRS (IRS) in 2008 possibly because of shrink in the market as a result of global financial crisis. 


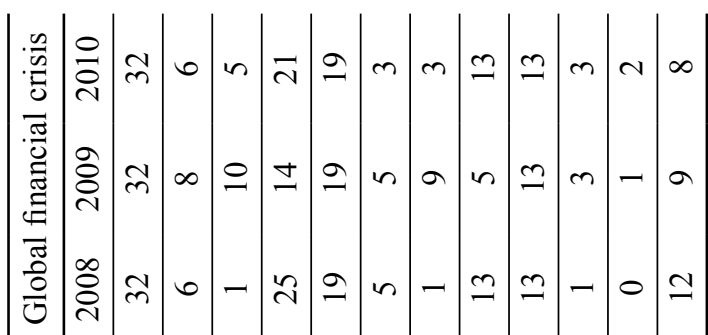

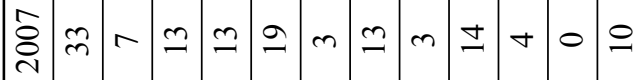

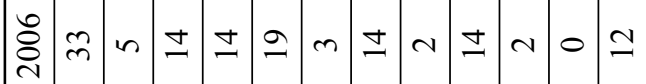

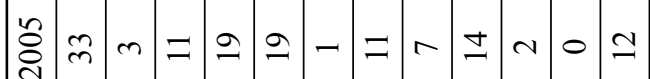

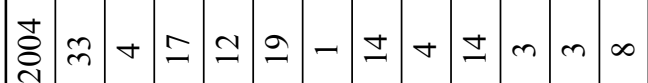

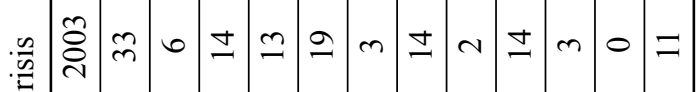

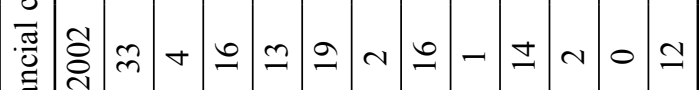
త్త్

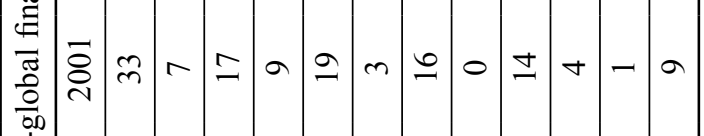

ปั่

Әे

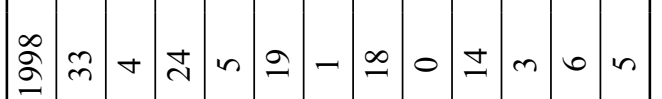

ăm $m$ m

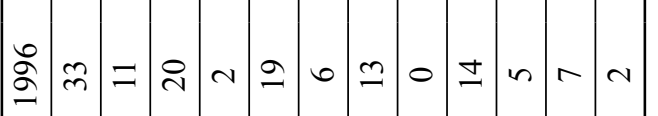

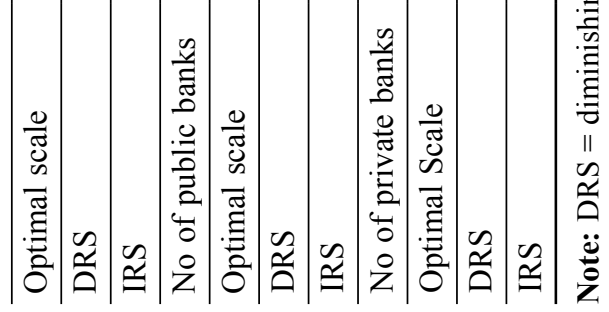

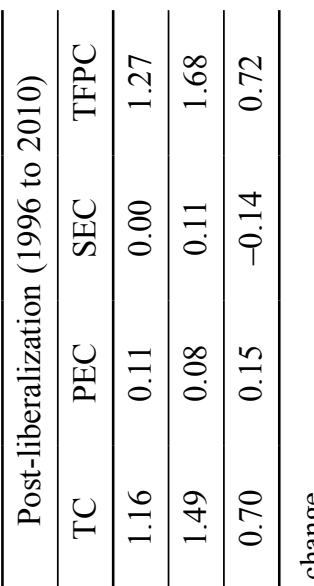

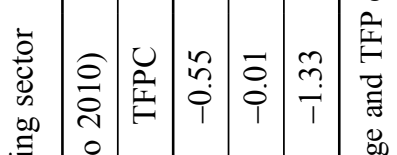

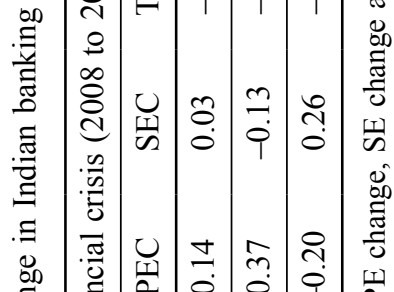

兽

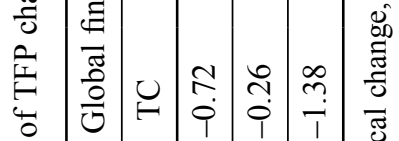

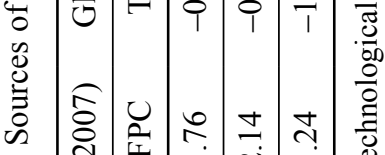

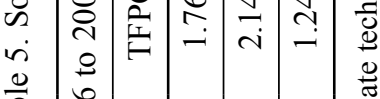
泀 


\subsection{Sources of TFP change}

The Malmquist productivity index can be decomposed into (i) TC (progress or regress), indicating how much benchmark production frontier shifts at each bank's observed input mix (innovation or shocks), (ii) PE change, indicating how much closer a bank gets to the efficient frontier, and (iii) SE change, indicating how much closer the banks are moving towards the most productive scale size. Table 5 reports the summary statistics of Malmquist productivity index and its components for the entire period as well as two sub-periods and their trends over the years are shown in Figure 1(g) to 1(j).

The average annual change of TFP in Indian banking sector is observed as $1.27 \%$ during the post-reform period, with an average annual change of $1.68 \%$ and $0.72 \%$ in public and private sector banks respectively. The difference in the TFP change between these two types of banks is found to be statistically significant. When we look at the contributions of different components towards TFP change, we observe that the TC has been the dominating source of productivity growth during the entire post reform period with average annual TC for all banks, PSBs and private banks as $1.16 \%, 1.49 \%$ and $0.70 \%$, respectively. On an average, Indian banking sector has achieved a positive growth of $1.76 \%$ in pre-global financial crisis period with an average annual growth of $2.14 \%$ and $1.24 \%$ respectively in public and private sector banks. However, the scenario in the global financial crisis period, as expected is somewhat discouraging. On an average, Indian banking sector suffer loss in TFP by $0.55 \%$ due to technological regress. The loss in TFP change during the crisis is found to be substantially high in private sector banks compared to PSBs as a result of technological regress as well as loss in PE.

\section{Conclusions}

Enticed by the reform in the early 1990s and further slowdown in the economy as a result of global financial crisis in late 2000s, the current study analyzes the performance of Indian banking sector based on ownership during the last 15 years of post liberalization period as well as two sub-periods within it, i.e., pre-global financial crisis (1996-2007) and global financial crisis (2008-2010). The technique of data envelopment analysis is used to measure the performance in terms of technical efficiency, returns to scale, and total factor productivity change for a sample of 33 banks, consisting of 19 public sector and 14 private sector banks. The findings reveal that the PSBs perform at par with private sector banks in terms of efficiency. The number of banks under IRS shows an increasing trend over the years during the post reform period. Hence, those banks with the IRS could achieve significant cost savings and efficiency gains by increasing the scale of their operations. In other words, substantial gains could be obtained from altering scale via internal growth or consolidation in the sector. Further, PSBs have performed better than its counterpart in terms of TFP change as a result of significant differences in technological change. The analysis for two different sub-periods reveals that in spite of global financial crisis, Indian banks continue to show increasing trends in efficiency. However, there is evidence of shrink in the market resulting in movement of the banks towards IRS as well as negative growth in TFP in both the sectors during 
a) Trends of technical efficiency

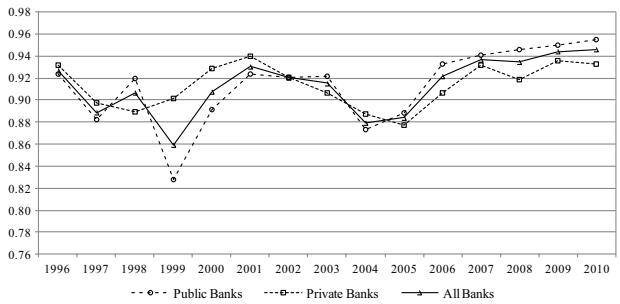

c) Trends of scale efficiency

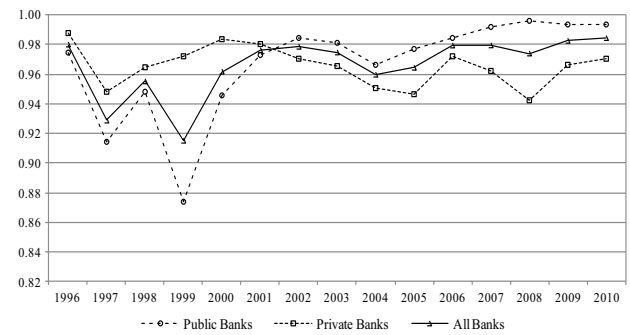

e) Percent of banks under decreasing returns to scale

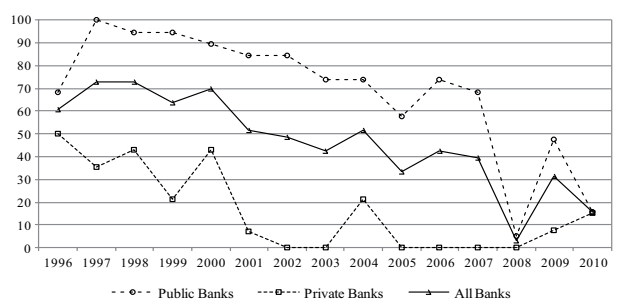

g) Trends of technological change

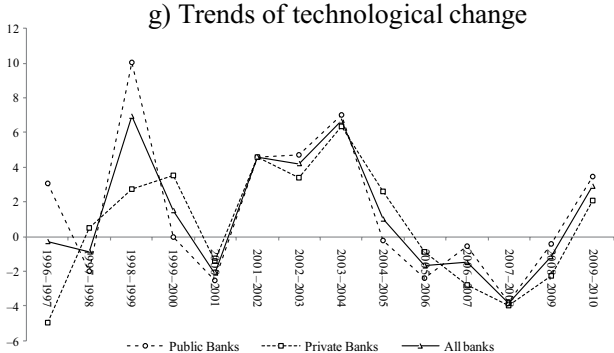

i) Trends of scale efficiency change

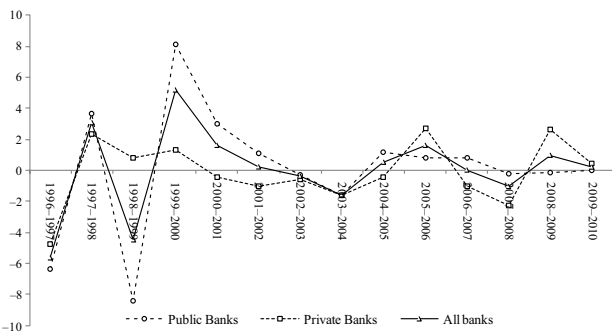

b) Trends of pure efficiency

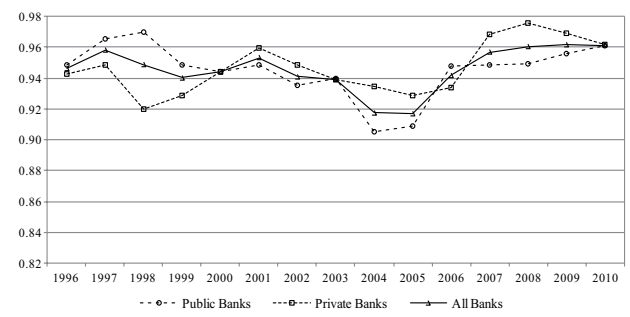

d) Percent of banks under optimal returns to scale

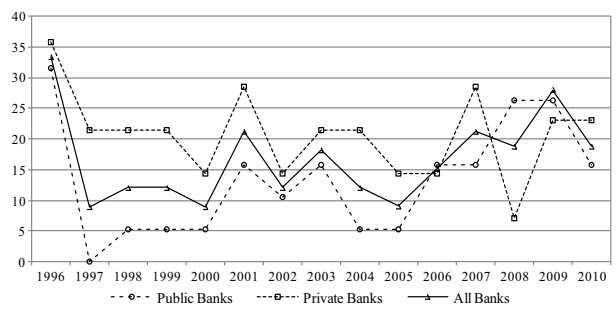

f) Percent of banks under increasing returns to scale

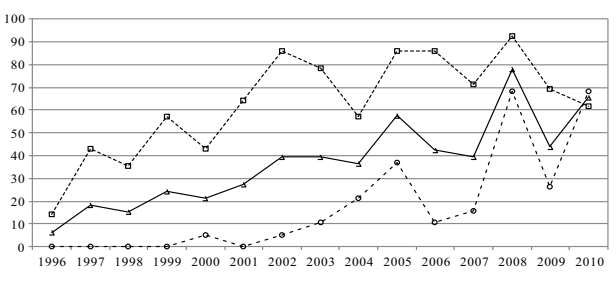

-. - - Public Banks -.-r-a. Private Banks $\rightarrow$ All Banks

h) Trends of pure efficiency change

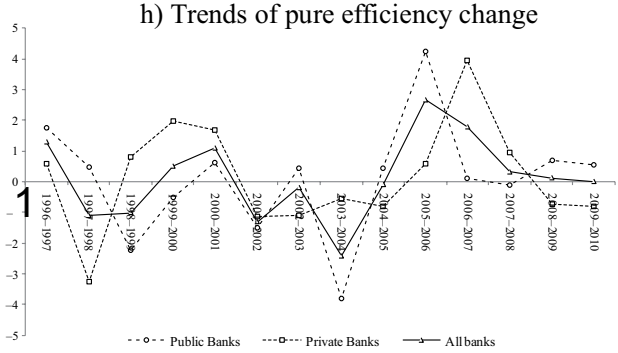

j) Trends of TFP change

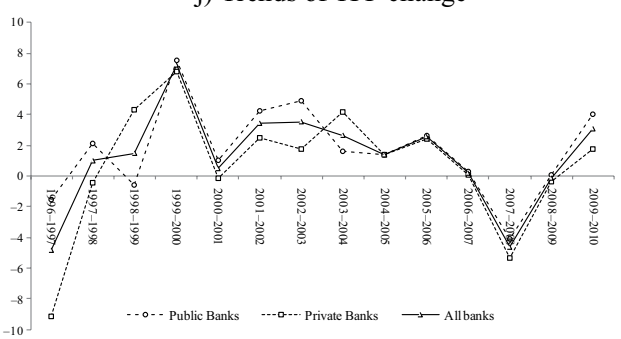

Fig. 1. Trends of performance indicators in Indian banking sector 
the period of global financial crisis. One of the future directions of the study could be to evaluate the performance of these banks by also taking into account of off balance-sheet business such as, lines of credit, loan commitments, securitization and derivatives with larger set of sample including the foreign banks. Further, production or value-added approach could be considered side-by-side to give further insight on banks' performance.

\section{Reference}

Afrait, S. N. 1972. Efficiency estimation of production functions, International Economic Review 13(3): 568-598. http://dx.doi.org/10.2307/2525845

Alam, S. I. M. 2001. A non-parametric approach for assessing productivity dynamics of large U.S. banks, Journal of Money, Credit and Banking 33(1): 121-139. http://dx.doi.org/10.2307/2673875

Avkiran, N. K. 1999. Productivity analysis in the services sector with data envelopment analysis. $1^{\text {st }}$ ed. Queensland: Camira.

Avkiran, N. K. 2000. Rising productivity of Australian trading banks under deregulation 19861995, Journal of Economics and Finance 24(2): 122-140. http://dx.doi.org/10.1007/BF02752708

Banker, R. D.; Charnes, A.; Cooper, W. W. 1984. Some models for estimating technical and scale inefficiencies in data envelopment analysis, Management Science 30(9): 1078-1092.

http://dx.doi.org/10.1287/mnsc.30.9.1078

Berg, S. A.; Forsund, F.; Jansen, E. S. 1992. Malmquist indices of productivity growth during the deregulation of Norwegian banking, 1980-1989, Scandinavian Journal of Economics 94: 211-228. http://dx.doi.org/10.2307/3440261

Berger, A.; Humphrey, D. 1997. Efficiency of financial institutions: international survey and directions for future research, European Journal of Operational Research 98(2): 175-212.

http://dx.doi.org/10.1016/S0377-2217(96)00342-6

Bhattacharya, A.; Lovell, C. A. K.; Sahay, P. 1997. The impact of liberalization on the productive efficiency of Indian commercial banks, European Journal of Operational Research 98(2): 332-345. http://dx.doi.org/10.1016/S0377-2217(96)00351-7

Bhide, M.G.; Prasad, A.; Ghosh, S. 2001. Banking sector reforms: a critical overview, Economic and Political Weekly 36(February-March): 399-408.

Canhoto, A.; Dermine, J. 2003. A note on banking efficiency in Portugal, new vs. old banks, Journal of Banking and Finance 27(11): 2087-2098. http://dx.doi.org/10.1016/S0378-4266(02)003163

Charles, V.; Kumar, M. 2012. Ranking Peruvian banks through super-efficiency DEA under variable returns to scale, in Charles, V.; Kumar, M. (Eds.). Data envelopment analysis and its applications to management. UK: Cambridge Scholars Publishing.

Charnes, A.; Cooper, W. W.; Rhodes, E. 1978. Measuring the efficiency of decision making units, European Journal of Operational Research 2(6): 429-444.

http://dx.doi.org/10.1016/0377-2217(78)90138-8

Coelli, T.; Rao, D. S. P.; Battese, G. E. 1998. An introduction to efficiency analysis. London: Kluwer Academic Publishers. http://dx.doi.org/10.1007/978-1-4615-5493-6

Das, A. 1997. Measurement of productive efficiency and its decomposition in Indian banking firms, Asian Economic Review 39(3): 422-439.

Färe, R. 1988. Fundamentals of production theory. Berlin: Springer-Verlag, http://dx.doi.org/10.1007/978-3-642-51722-8

Färe, R.; Grosskopf, S.; Norris, M.; Zhang, Z. 1994. Productivity growth, technical progress, and efficiency change in industrial countries, American Economic Review 84(1): 66-83. 
Farrell, M. J. 1957. The measurement of productive efficiency, Journal of the Royal Statistical Society 120(3): 253-281. http://dx.doi.org/10.2307/2343100

Galagedera, D. U. A.; Edirisuriya, P. 2005. Performance of Indian commercial banks (19952002), South Asian Journal of Management 12(4): 52-74. http://dx.doi.org/10.2307/2343100

Gilbert, R. Al.; Wilson, P. W. 1998. Effect of deregulation on the productivity of Korean banks, Journal of Economics and Business 50(2): 133-155.

http://dx.doi.org/10.1016/S0148-6195(97)00074-X

Isik, I.; Hassan, M. K. 2003. Financial deregulation and total factor productivity change: an empirical study of Turkish commercial banks, Journal of Banking and Finance 27(8): 1455-1485. http://dx.doi.org/10.1016/S0378-4266(02)00288-1

Kao, C.; Liu, S. 2004. Predicting bank performance with financial forecasts: a case of Taiwan commercial banks, Journal of Banking \& Finance 28(10): 2353-2368.

http://dx.doi.org/10.1016/j.jbankfin.2003.09.008

Kumar, M.; Charles, V. 2011. Benchmarking Indian banks using DEA in cost-liberalization period: progressive time-weighted mean approach, The Service Industries Journal 31(14): 24552485. http://dx.doi.org/10.1080/02642069.2010.504818

Kumar, L.; Malthy, D.; Ganesh, L. S. 2010. Productivity growth and efficiency change in Indian banking: technology effect vs. catch-up effect, Journal of Advances in Management Research 7(2): 194-218. http://dx.doi.org/10.1108/09727981011084995

Kumbhakar, S. C.; Lozano-Vivas, A.; Lovell, C. A. K.; Hasan, I. 2001.The effect of deregulation on the performance of financial institutions: the case of Spanish saving banks, Journal of Money, Credit and Banking 33(1): 101-119. http://dx.doi.org/10.2307/2673874

Kumbhakar, S. C.; Sarkar, S. 2005. Deregulation, ownership and efficiency change in Indian banking: an application of stochastic frontier analysis, in Ghosh R.; Neogi C. (Eds.). Theory and Application of Productivity and Efficiency: Econometric and DEA Approach. New Delhi: Macmillan. http://dx.doi.org/10.2307/2673874

Mohan, R. 2008. Global financial crisis and key risks: impact on India and Asia: remarks prepared for IMF-FSF high-level meeting on recent financial turmoil and policy responses. Washington, DC.

Nunamaker, T. R. 1985. Using data envelopment analysis to measure the efficiency of non-profit organizations, Managerial and Decision Making 6(1): 50-58.

http://dx.doi.org/10.1002/mde.4090060109

Prasad, A.; Ghosh, S. 2007. Competition in Indian banking: an empirical evaluation, South Asia Economics Journal 8(2): 265-284.

Prasad, A.; Reddy, C. P. 2009. Global financial crisis and its impact on India, Journal of Social Sciences 21(1): 1-5. http://dx.doi.org/10.1177/139156140700800205

Ram Mohan, T. T.; Ray, S. C. 2004. Productivity growth and efficiency in Indian banking: a comparison of public, private, and foreign banks, Economics Working Paper 2004-27. Department of Economics, University of Connecticut, Storrs, CT.

Raab, R.; Lichty, R. 2002. Identifying sub-areas that comprise a greater metropolitan area: the criterion of country relative efficiency, Journal of Regional Science 42(3): 579-594.

http://dx.doi.org/10.1111/1467-9787.00273

Ray, S. C.; Desli, E. 1997. Productivity growth, technical progress, and efficiency changes in industrialized countries: comment, American Economic Review 87(5): 1033-1039.

Reddy, Y. V. 2006. Reforming India's financial sector: changing dimensions and emerging issues. International Center for Monetary and Banking Studies, Geneva.

Saha, A.; Ravisankar, T. S. 2000. Rating of Indian commercial banks: a DEA approach, European Journal of Operational Research 124(1): 187-203. http://dx.doi.org/10.1016/S0377-2217(99)00167-8 
Sahoo, B. K.; Sengupta, J. K.; Mandal, A. 2007. Productive performance evaluation of the banking sector in India using data envelopment analysis, International Journal of Operations Research 4(2): 63-79.

Sathye, M. 2003. Efficiency of banks in a developing economy: the case of India, European Journal of Operational Research 148(3): 662-671. http://dx.doi.org/10.1016/S0377-2217(02)00471-X Shephard, R. W. 1970. Theory of cost and production function. Princeton: Princeton University Press.

Sturm, J.-E.; Williams, B. 2004. Foreign bank entry, deregulation and bank efficiency: lessons from the Australian experience, Journal of Banking and Finance 28(7): 1775-1799.

http://dx.doi.org/10.1016/j.jbankfin.2003.06.005

Subbarao, D. 2009. Impact of the global financial crisis on India collateral damage and response, in Symposium on The Global Economic Crisis and Challenges for the Asian Economy in a Changing World, 4 November 2009, The Institute for International Monetary Affairs, Tokyo.

Yeh, Q. J. 1996. The application of data envelopment analysis in conjunction with financial ratios for bank performance evaluation, Journal of the Operational Research Society 47(8): 980-988. http://dx.doi.org/10.1057/jors.1996.125

Zhao, T.; Casu, B.; Ferrari, A. 2008. Deregulation and productivity growth: a study of the Indian commercial banking industry, International Journal of Business Performance Management 10(4): 318-343. http://dx.doi.org/10.1504/IJBPM.2008.019990

Mukesh KUMAR. He is a full-time Professor and Principal Investigator at CENTRUM Católica Graduate Business School. His area of research interest includes performance measurement including efficiency, productivity and service quality.

Vincent CHARLES. He is currently with CENTRUM Católica Graduate Business School as the Director of CENTRUM Research, and as a full professor and distinguished researcher. His area of research interest includes stochastic quantitative analytics, product/service innovation and performance management.

Chandra SEKHAR MISHRA. He is an Assistant Professor at VGSOM, IIT Kharagpur. His areas of research are financial performance analysis, valuation and mergers $\&$ acquisitions. 